\title{
COMBINATION OF NAA AND TDZ FOR In Vitro MULTIPLICATION OF Eugenia involucrata $\mathrm{DC}^{1}$
}

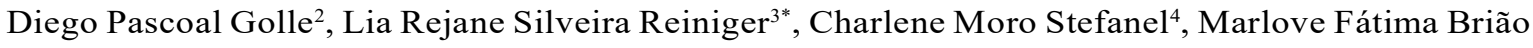
Muniz $^{5}$ and Karol Buuron da Silva ${ }^{4}$

\footnotetext{
${ }^{1}$ Received on 20.04.2015 accepted for publication on 04.10.2017.

${ }^{2}$ Universidade de Cruz Alta, Pró-Reitoria de Pós-Graduação, CruzAlta, Rio Grande do Sul - Brasil. E-mail: <diego.golle@gmail.com>. ${ }^{3}$ Universidade Federal de Santa Maria, Departamento de Fitotecnia, Santa Maria, Rio Grande do Sul - Brasil. E-mail: $<$ liarsr@ufsm.br>. ${ }^{4}$ Universidade Federal de Santa Maria, Programa de Pós-Graduação em Engenharia Florestal, Santa Maria, Rio Grande do Sul - Brasil.E-mail: <charlenestefanel@yahoo.com.br>and <karolbuuron@hotmail.com>.

${ }^{5}$ Universidade Federal de Santa Maria, Departamento de Defesa Fitossanitária, Santa Maria, Rio Grande do Sul - Brasil. E-mail: <marlovemuniz@yahoo.com.br>.

*Corresponding author.
}

\begin{abstract}
Eugenia involucrata DC. (Myrtaceae), an economically important forest tree species, is prized for its timber and fruits, and is also an important ornamental plant. This study aimed to evaluate the effect of Thidiazuron (TDZ) and $\alpha$-Naphthaleneacetic acetic acid (NAA) on in vitro multiplication of nodal segments of E. involucrata. We tested the effect of the absence and presence of NAA $(0.5 \mu \mathrm{M})$, combined with TDZ at concentrations of $0,2,4,8,16$, or $32 \mu \mathrm{M}$, on the in vitro multiplication of E. involucrata. The use of TDZ combined with NAA $(0.5 \mu \mathrm{M})$ favored the formation of shoots and buds in the explants, especially at $32 \mu \mathrm{M}$ TDZ concentration. Intermediate concentrations of TDZ also promoted shoot formation but induced hyperhydricity in the explants. It is possible to induce organogenesis leading to the multiplication of E. involucrata nodal segments using TDZ, preferably combined with NAA.
\end{abstract}

Keywords: Micropropagation; Adventitious buds; Organogenesis.

\section{COMBINAÇÕES DE ANA E TDZ NA MULTIPLICAÇÃO In Vitro DE Eugenia involucrata $D C$}

\begin{abstract}
RESUMO - Eugenia involucrata DC. (Myrtaceae) é uma espécie florestal com potencialidade econômica, para uso madeireiro, frutícola e ornamental. Este trabalho objetivou avaliar o efeito de Thidiazuron (TDZ) e Ácido $\alpha$-Naftaleno Acético (ANA) sobre a multiplicação in vitro de segmentos nodais de E. involucrata. Foi testada a ausência e a presença de ANA (a 0,5 $\mu \mathrm{M})$ combinadas ao TDZ nas concentrações $0,2,4$, 8,16 ou $32 \mu M$ sobre algumas variáveis da multiplicação in vitro de E. involucrata. O uso de TDZ combinado a ANA (a 0,5 $\mu \mathrm{M})$ favoreceu a emissão de brotações e de gemas nos explantes, especialmente a $32 \mu \mathrm{M}$. Concentrações intermediárias de TDZ também promoveram brotações, mas induziram à ocorrência de hiperidricidade nos explantes. É possível multiplicar e induzir segmentos nodais de E. involucrata à organogênese na presença de TDZ, preferencialmente combinado com ANA.
\end{abstract}

Palavras-Chave: Micropropagação; Gemas adventicias; Organogênese. 


\section{INTRODUCTION}

Eugenia involucrata DC. belongs to the family Myrtaceae, and naturally occurs in several Brazilian states, ranging from Rio Grande do Sul to Minas Gerais. It has medicinal properties and economic potential as a source of timber and fruits, and has substantial ornamental use as well. However, E. involucrata propagation is hindered because its seeds are recalcitrant, that is, they lose viability when stored (Backes and Irgang, 2002; Carvalho, 2008; Lorenzi, 2008).

Similar to other forest tree species, E. involucrata requires a long time to reach reproductive and phenotypic maturity. Crossing processes are also arduous, limiting eventual plant breeding programs (Tzfira et al., 1998; Resende, 2001). A possible alternative to speed up these programs consists of the use of tissue culture techniques that have the advantages of possible in vitro conservation of the germplasm, propagation of superior clones, production of pathogen-free cultures, and patenting of biotechnological processes and materials. Furthermore, in vitro cultures may be the source material for other procedures, such as genetic transformation (Xavier et al., 2007).

Optimization of in vitro propagation from shoots may be applied to fast clonal propagation of E. involucrata seedlings, thereby hastening the multiplication of individuals with essential agronomic characteristics for use in plant breeding programs. Micropropagation of woody species has been studied through the evaluation of physiological responses in the presence of several types of exogenous cytokines. The most frequently used micropropagation protocols include 6-benzylaminopurine (BAP). However, kinetin (KIN) and Thidiazuron (TDZ) have shown promising results as well (Oliveira et al., 2013). Cytokines are often combined with auxins, and have been used to produce propagules by means of in vitro multiplication (Hinojosa, 2000).

Auxins induce cell division and control cell growth and elongation (Li et al., 2010), while cytokines promote cell division and adventitious bud formation (Barrueto, 2000). TDZ is a cytokine frequently used in the tissue culture of woody species. TDZ is usually required at higher concentrations than other cytokines, such as aminopurines (Sujatha and Hazra, 2007).

The objective of the present work was to evaluate the in vitro multiplication of $E$. involucrata using different phytoregulators combinations in the presence or absence of $\alpha$-Naphthaleneacetic acid (NAA) and distinct TDZ concentrations.

\section{MATERIALAND METHODS}

The experiment was carried out in the Laboratory of Plant Tissue Culture at the Nucleus of Biotechnology and Plant Breeding, Department of Crop Plants, Federal University of Santa Maria (UFSM), Rio Grande do Sul. Parent plants were grown in a greenhouse, and at 36months old they were used for explant isolation. These plants were trimmed approximately four weeks before the explants were collected for the production of young shoots and kept in vases (depth $-22 \mathrm{~cm}$, diameter $24 \mathrm{~cm}$, volume approximately $8 \mathrm{~L}$ ) filled with the Plantmax ${ }^{\circledR}$ substrate. Plants were irrigated daily, and every 15 days, $400 \mathrm{~mL}$ of a $1 \mathrm{~g} \mathrm{~L}^{-1}$ solution containing nitrogen, phosphorus, and potassium (N-P-K: 5-20-20) were added to the substrate, which was supplemented with 400 $\mathrm{mL}$ at $1 \mathrm{~g} \mathrm{~L}^{-1} \mathrm{~N}$ (urea) once a week. One day before the weekly collection of the explants, the plants were sprayed until saturation with a solution containing $1 \mathrm{~g} \mathrm{~L}^{-1}$ Cercobin700PM ${ }^{\circledR}$ (Thiophanate-methyl) and $0.1 \mathrm{~g} \mathrm{~L}^{-1}$ streptomycin sulfate. This procedure was a pre-treatment that facilitated surface disinfestation of the explants in the laboratory.

Young branches with a green color and no woody areas present between the third and fourth nodal segments were selected for the experiment. The most apical segment was discarded, and the most basal segment was also discarded if it appeared woody or more developed than the other parts. Some of the leaves were removed upon collection, and the segments were placed in distilled water with $1 \mathrm{~g} \mathrm{~L}^{-1}$ Benlate $500^{\circledR}$ (Benomyl) and $0.1 \mathrm{~g} \mathrm{~L}^{-1}$ streptomycin sulfate for approximately $30 \mathrm{~min}$. In the laboratory, the branches were washed for 5 min under running water with a commercial detergent using a sponge. The nodal segments were cut in a laminar flow chamber and subsequently subjected to surface disinfestation as follows: immersion in $70 \%$ $(\mathrm{v} / \mathrm{v})$ ethanol for $30 \mathrm{~s}$, a wash with distilled water, agitation in a $1.5 \%(\mathrm{v} / \mathrm{v})$ sodium hypochloride solution $(\mathrm{NaOCl})$ for $15 \mathrm{~min}$, immersion in a $0.05 \%(\mathrm{w} / \mathrm{v})$ mercury bichloride $\left(\mathrm{HgCl}_{2}\right)$ solution for $10 \mathrm{~min}$, a wash with sterile water, and immersion for $10 \mathrm{~min}$ in a $1.5 \%(\mathrm{v} / \mathrm{v}) \mathrm{NaOCl}$ solution with three drops of commercial detergent added to break the surface tension. Finally, the material was rinsed three times with sterile water.

Revista Árvore. 2017;41(5):e410509 
After the last rinse, the explants remained in a sterile water solution containing $100 \mathrm{mg} \mathrm{L}^{-1}$ ascorbic acid. Leaf remains were removed from the nodal segments, which were then cut $0.3 \mathrm{~cm}$ above and $0.8 \mathrm{~cm}$ below the node. Bevel cuts were performed in the basal region to increase the surface area in contact with the nutritive medium.

The experiment was conducted with a completely randomized design in a $2 \times 6$ factorial array. The levels of the " $A$ " factor were defined by the absence or presence (at $0.5 \mu \mathrm{M}$ ) of $\alpha$-NAA, while the levels of the factor " $\mathrm{B}$ " referred to different TDZ concentrations $(0,2,4$, $8,16$, or $32 \mu \mathrm{M})$. Eight replicates were performed with two explants each, for a total of 96 experimental units and 192 inoculated nodal segments. Each experimental unit consisted of a $150-\mathrm{mL}$ glass flask containing 30 mL MS nutritive medium (Murashige and Skoog, 1962) with half the normal salt concentration ( $1 / 2 \mathrm{MS}), 30 \mathrm{~g}$ $\mathrm{L}^{-1}$ sucrose, $50 \mathrm{mg} \mathrm{L}^{-1}$ myoinositol, and $7 \mathrm{~g} \mathrm{~L}^{-1}$ agar. The $\mathrm{pH}$ of the medium was adjusted to 5.8 after supplementation with phytoregulators but before the addition of agar. Flasks were covered with aluminum foil and autoclaved at $121^{\circ} \mathrm{C}$ and $1.5 \mathrm{~atm}$ for $20 \mathrm{~min}$.

After 60 days of culture, the following variables were evaluated: average number of shoots per explant, average number of buds produced per explant (counting only the adventitious buds generated by tissue organogenesis and not for the pre-existing buds frequently found in nodal segments), average number of leaves per explant, the percentage (\%) of nodal segments forming calli at the base, and hyperhydricity (\%).

The data were tested for normality using the Kolmogorov-Smirnov test and for homogeneity using Bartlett's test, and, when required, transformed using the following equation: $\sqrt{x+0,5}$. The data were then subjected to an analysis of variance. The qualitative analyses were carried out using Tukey's test at a 5\% significance level, while the quantitative analyses were carried out by polynomial regression. All statistical analyses were performed using the software SISVAR (Ferreira, 2014).

\section{RESULTS}

There was a significant effect of the interaction $(p=0.0021)$ between the phytoregulators tested on the variable number of shoots produced per explant (Figure 1). In the absence of NAA, it was not possible to adjust the behavior of the explants to a polynomial equation. The highest average number of shoots produced per explant (1.95) occurred in the absence of TDZ. Nevertheless, the combination of different TDZ concentrations with $0.5 \mu \mathrm{M}$ NAA allowed for the fit at a quadratic equation. In the absence of TDZ, the number of shoots was higher than that observed for most of the concentrations tested, with the lowest value, according to calculations, associated with $11.62 \mu \mathrm{M}$ TDZ. However, above that value, the number of shoots increased with increasing TDZ concentration, reaching a maximum at $32 \mu \mathrm{M}$ TDZ when an average of 2.0 shoots were produced per explant.

Regarding the formation of adventitious buds (Figure 2), there was again a significant effect of interaction $(p=0.0047)$ between the phytoregulators tested. In the absence of NAA and at TDZ concentrations of $0,2,4$, or $8 \mu \mathrm{M}$, no buds were produced. Buds were observed only at $16(0.28)$ and $32 \mu \mathrm{M}(2.83) \mathrm{TDZ}$. Bud

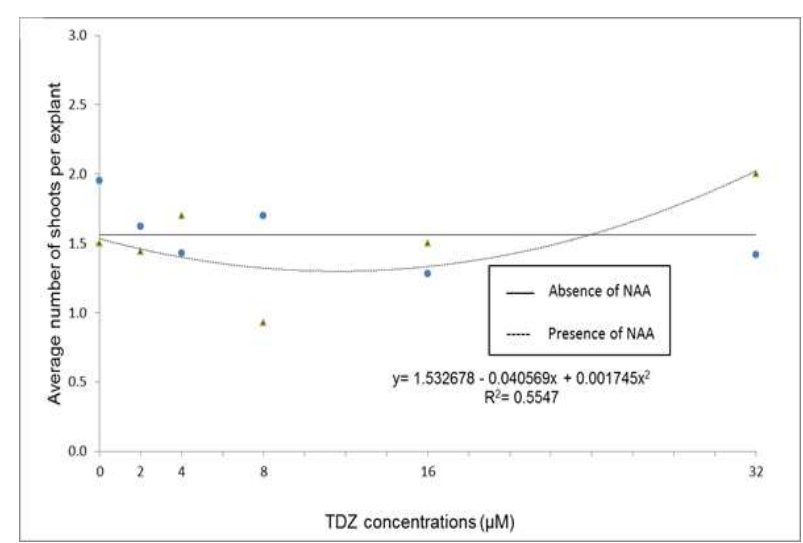

Figure 1 - Average number of shoots produced in nodal segments of Eugenia involucrata DC. as a function of the interaction between the absence or presence of aNaphthaleneacetic acid (NAA; at $0.5 \mu \mathrm{M}$ ) and Thidiazuron (TDZ) at $0,2,4,8,16$, or $32 \mu \mathrm{M}$ after 60 days of in vitro culture on $1 / 2$ MS nutritive medium. Santa Maria, RS, UFSM, 2010.

Figura 1-Média de brotações emitidas em segmentos nodais de Eugenia involucrata DC. em função da interação entre a ausência ou presença $(a 0,5 \mu M)$ de Ácido á-Naftalenoacético (ANA) e concentrações 0, 2, 4, 8, 16 ou $32 \mu M$ de Thidiazuron (TDZ), aos 60 dias de cultivo in vitro em meio nutritivo $M S$, cuja concentração de sais foi reduzida à metade ( $1 / 2 M S)$. Santa Maria, RS, UFSM, 2010.

Revista Árvore. 2017;41(5):e410509 
formation in the absence of NAA fit a linear model, with the production of buds increasing with increasing TDZ concentration. The use of $0.5 \mu \mathrm{M}$ NAA resulted in a positive linear relationship between variable bud formation and the increase in the number of buds per explant following increase in TDZ concentrations. No buds were produced at TDZ concentrations of 0,2 , and $4 \mu \mathrm{M}$, but were produced only at $8(0.67), 16(1.57)$, and $32 \mu \mathrm{M}$ (2.50) of TDZ.

Similarly, there was a significant interaction $(p=0.0259)$ between phytoregulators tested and the number of leaves produced per explant (Figure 3 ). In the absence of NAA, the variable fitted a quadratic behavior, with a reduction in the number of leaves per explant at lower TDZ concentrations, reaching the lowest value at $16 \mu \mathrm{M}(1.66)$. According to the calculated value for the vertex of the equation, the fewest number of leaves would have been produced at a TDZ concentration of $16.33 \mu \mathrm{M}$. In the presence of $0.5 \mu \mathrm{M}$ NAA it was not possible to adjust the values observed to any mathematical model. The highest values for the number of leaves per explant occurred at TDZ concentrations of 0 (2.22), 16 (2.08), and 32 (2.08) $\mu \mathrm{M}$,

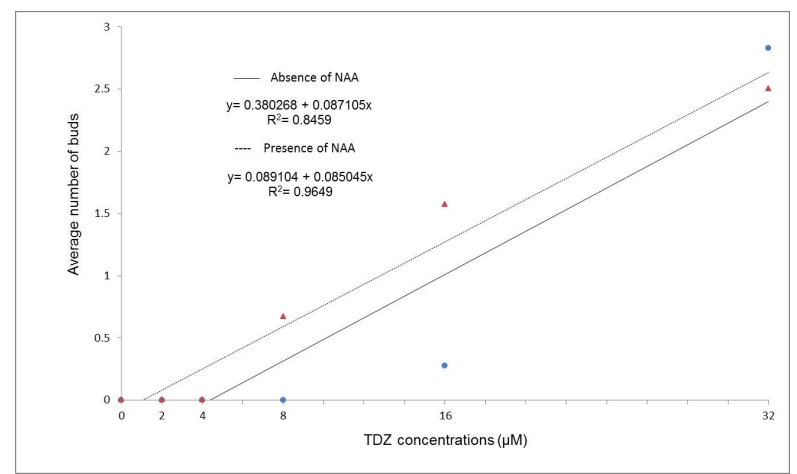

Figure 2 - Average number of adventitious buds produced in the nodal segments of Eugenia involucrata DC. as a function of the interaction between the absence or presence of a-Naphthaleneacetic acid (NAA; at $0.5 \mu \mathrm{M}$ ) and Thidiazuron (TDZ) at $0,2,4,8$, 16 , or $32 \mu \mathrm{M}$ after 60 days of in vitro culture on $1 / 2$ MS nutritive medium. Santa Maria, RS, UFSM, 2010.

Figura 2-Média de gemas adventícias emitidas em segmentos nodais de Eugenia involucrata DC. em função da interação entre a ausência ou presença $(a 0,5 \mu M)$ de Ácido á-Naftalenoacético (ANA) e concentrações $0,2,4,8,16$ ou $32 \mu M$ de Thidiazuron (TDZ), após 60 dias de cultivo in vitro em meio nutritivo $M S$, cuja concentração de sais foi reduzida à metade (1/2MS). Santa Maria, RS, UFSM, 2010. whereas the lowest values were observed at 2 (1.59), 4 (1.85) and 8 (1.32) $\mu \mathrm{M}$ of TDZ.

Regarding the formation of calli, which were particularly evident at the base of the explants, there was no significant interaction between the phytoregulators tested and calli formation. Nevertheless, changes occurred $(p=0.0004)$ in response to different TDZ concentrations in a quadratic model (Figure 4). In the absence of TDZ, a lower percentage of explants (34.37\%) formed calli. This value was higher at TDZ concentrations of $2(54.12 \%), 4(79.28 \%)$, and $8 \mu \mathrm{M}$ $(81.25 \%)$. According to the calculated vertex of the equation, the TDZ concentration that resulted in the highest percentage of callus formation was $16.21 \mu \mathrm{M}$. However, reduced values for calli formation were observed at $16 \mu \mathrm{M}(63.37 \%)$ and $32 \mu \mathrm{M}(53.12 \%)$ of TDZ.

A significant interaction $(\mathrm{p}=0.0000)$ between the phytoregulators tested and explant hyperhydricity was found (Figure 5). In the absence of NAA, hyperhydricity displayed quadratic behavior as a function of the TDZ concentration. The highest percentage of hyperhydricity (40\%) occurred at $8 \mu \mathrm{M}$ TDZ. According to the calculated value for the vertex of the polynomial equation, that percentage would have reached a maximum at 15.70

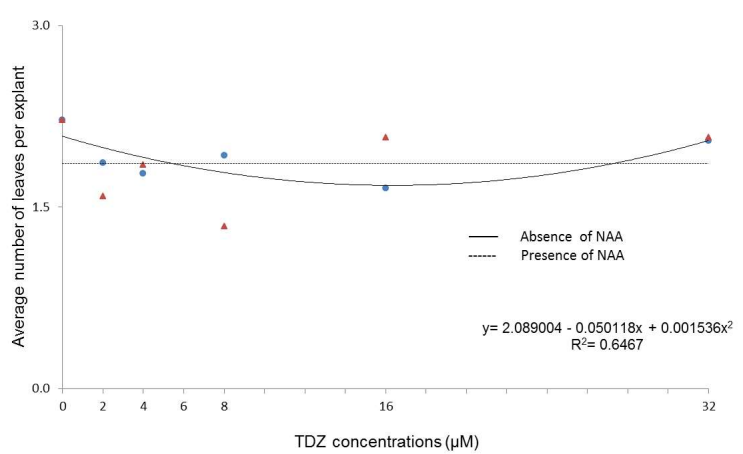

Figure 3 - Average number of leaves produced on nodal segments of Eugenia involucrata DC. as a function of the interaction between the absence or presence of a-Naphthaleneacetic acid (NAA; at $0.5 \mu \mathrm{M}$ ) and Thidiazuron (TDZ) at 0 , $2,4,8,16$, or $32 \mu \mathrm{M}$ after 60 days of in vitro culture on $1 / 2$ MS nutritive medium. Santa Maria, RS, UFSM, 2010.

Figura 3 - Média de folhas emitidas em segmentos nodais de Eugenia involucrata DC. em função da interação entre a ausência ou presença $($ a $0,5 \mu \mathrm{M})$ de Ácido á-Naftalenoacético (ANA) e concentrações 0, 2, 4, 8, 16 ou $32 \mu$ Mde Thidiazuron (TDZ), após 60 dias de cultivo in vitro, em meio nutritivo MS, cuja concentração de sais foi reduzida à metade (1/2MS). Santa Maria, RS, UFSM, 2010. Santa Maria, RS, UFSM, 2010.

Revista Árvore. 2017;41(5):e410509 
$\mu \mathrm{M}$. Above this concentration, callus formation tends to decrease. In the presence of NAA, the resulting hyperhydricity was $9.05 \%$, and it was not possible to adjust the values to any mathematical model.

\section{DISCUSSION}

Regarding the number of variable shoots produced by explants, high TDZ concentrations combined with NAA promoted bud formation. The initial reduction in the number of buds produced is potentially associated with the swelling of the budding regions of the explantsthe location of the dormant buds - and increasing TDZ concentrations. That decrease occurred mostly in the interval between the TDZ concentrations of 2 and 16 $\mu \mathrm{M}$. However, the highest concentration provided the required stimulus to increase the number of buds produced per explant.

We can infer that at the lowest concentrations the balance between auxin and cytokine was not adequate for the formation of shoots, since in addition to the exogenous source, it is highly likely that the explants had sufficient endogenous levels of auxin to balance the exogenous cytokine, favoring tumescence. However, the elevated cytokine levels promoted shoot production.

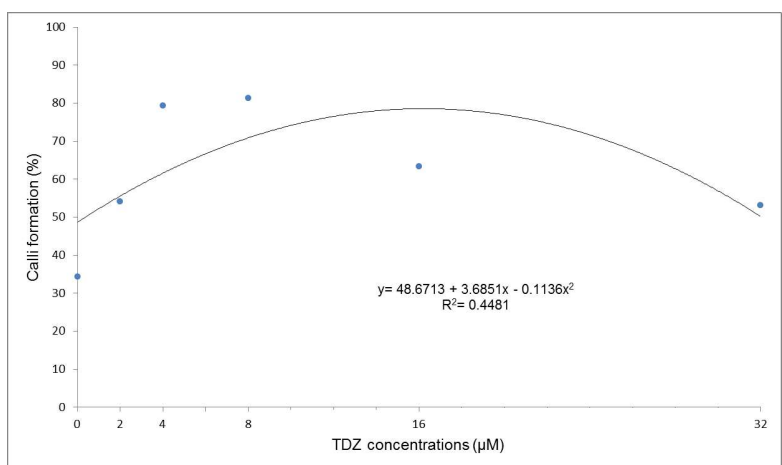

Figure 4 - Average percentage of Eugenia involucrata DC. nodal segments forming calli as a function of Thidiazuron (TDZ) concentration $(0,2,4,8,16$, or $32 \mu \mathrm{M})$, regardless of the absence or presence of a-Naphthaleneacetic acid (NAA; at $0.5 \mu \mathrm{M}$ ) after 60 days of in vitro culture on $1 / 2 \mathrm{MS}$ nutritive medium. Santa Maria, RS, UFSM, 2010.

Figura 4-Porcentagem média de formação calogênica em segmentos nodais de Eugenia involucrata DC. em função das concentrações $0,2,4,8,16$ ou $32 \mu M$ de Thidiazuron (TDZ), independentemente da ausência ou presença (a $0,5 \mu M$ ) de Ácido á-Naftalenoacético (ANA), após 60 dias de cultivo in vitro em meio nutritivo $M S$, cuja concentração de sais foi reduzida à metade ( $1 / 2 M S)$. Santa Maria, RS, UFSM, 2010.
Similar observations were made by Faisal et al. (2005) in Rauvolfia tetraphylla, in which there was an increase in the number of shoots produced by nodal segments due to the supplementation of the nutritive medium with TDZ. However, the intermediate concentrations were more propitious to multiplication than the highest concentration tested, in contrast with the results of the present study with E. involucrata. However, the highest concentration tested on $R$. tetraphylla did not correspond to even one third of the concentration that best promoted E. involucrata multiplication.

The largest number of shoots regenerated with TDZ in Tectona grandis were observed at a concentration of $8.8 \mu \mathrm{M}$ (Fermino Júnior et al., 2014). TDZ was used in the in vitro multiplication of $T$. grandis shoots (Akram and Aftab, 2008), and was the most efficient in the protocol proposed by Kozgar and Shahzad (2012), followed by CIN and BAP. TDZ also promoted the highest multiplication rates for Cassia angustifolia nodal segments, both alone and in combination with NAA or Indolacetic Acid (IAA) (Siddique and Anis, 2007). Similarly, the positive effect of TDZ was evident on

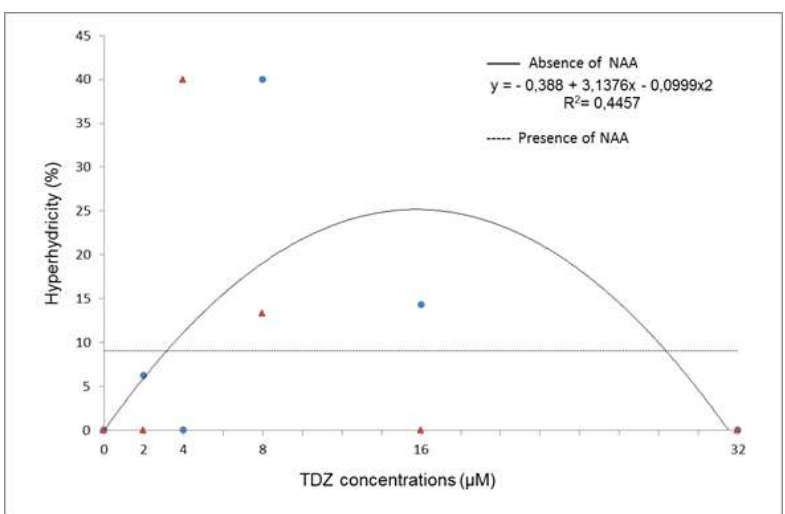

Figure 5-Average percentage of hyperhydricity in nodal segments of Eugenia involucrata DC. as a function of the interaction between the absence or presence of a-Naphthaleneacetic acid (NAA; at $0.5 \mu \mathrm{M}$ ) and Thidiazuron (TDZ) at 0 $2,4,8,16$, or $32 \mu \mathrm{M}$ after 60 days of in vitro culture on $1 / 2$ MS nutritive medium. Santa Maria, RS, UFSM, 2010.

Figura 5-Porcentagem de hiperidricidade em segmentos nodais de Eugenia involucrata DC. em função da interação entre a ausência oupresença (a 0,5 $\mu$ M) de Ácidoá-Naftalenoacético (ANA) e concentrações 0, 2, 4, 8, 16 ou $32 \mu \mathrm{Mde}$ (Thidizuron) TDZ, após 60 dias de cultivo in vitro, em meio nutritivo MS, cuja concentração de sais foi reduzida à metade (1/2MS). Santa Maria, RS, UFSM, 2010.

Revista Árvore. 2017;41(5):e410509 
the multiplication of Balanites aegyptiaca (Siddique and Anis, 2009). In this case, the highest TDZ concentration tested was $13.6 \mu \mathrm{M}$, well below the optimal concentration of $32 \mu \mathrm{M}$ for E. involucrata, according to the results of the present study.

With respect to the presence of adventitious buds, there was a synergism between NAA and TDZ. Similar to what we observed for E. involucrata, an increase in the TDZ concentration in the nutritive medium induced bud formation in Pinus pinea (Cortizo et al., 2009). In Ricinus communis, bud induction was evident when TDZ was used at a concentration of $2.5 \mathrm{mg} \mathrm{L}^{-1}$ (Sousa, 2013).

Fewer leaves were produced in the absence of the phytoregulators as well as in the presence of TDZ alone, either at 16 or $32 \mu \mathrm{M}$. At the tested concentrations, the combined use of NAA and TDZ was not effective in promoting the production of E. involucrate leaves. In the in vitro culture of Caesalpinia pyramidalis, the largest number of leaves was also observed when no phytoregulators were added to the nutritive medium. However, the smallest averages were observed when higher TDZ concentrations were used (Silva et al., 2013). Likewise, in Thymus vulgaris, the largest number of leaves was produced at an NAA concentration of $2.7 \mu \mathrm{M}$ (Rubin et al., 2007).

The number of leaves plays an important role during in vitro multiplication, since it is at the insertion between the stem and leaf that buds are form, thus potentially producing new shoots and increasing the production of new seedlings (Costa et al., 2010). Additionally, plants with a larger number of leaves have better chances of survival in nature, as leaves are responsible for utilizing sunlight to fix organic matter through photosynthesis (Moreira et al., 2006).

Callus formation was higher in the presence of phytoregulators. The supplementation of the nutritive medium with these compounds often results in callus induction in E. involucrata (Golle, 2010) and other species, such as Morinda citrifolia (Baque et al., 2010), Hyptis leucocephala (Pereira et al., 2012), Litchi chinensis (Ma et al., 2009), and Passiûora cincinnata (Silva et al., 2009; Pinto et al., 2010).

Besides phytoregulators, the type of explant affects callus formation, as observed with E. involucrata in another study, in which leaf discs showed a higher percentage of callogenesis (Golle, 2010) compared with apical and nodal segments (Golle and Reiniger, 2013). Nevertheless, in the present work, in which we aimed to evaluated the multiplication of E. involucrata explants, callus formation was not desired.

In general, hyperhydricity did not occur as is typical; the low development of the explants lead to the vitreous aspects of the leaves produced and they easily broke upon touching. Hyperhydricity was observed at intermediate TDZ concentrations. However, as the concentration increased, this phenomenon no longer appeared in the cultures. The observed hyperhydricity may have been caused by factors other than the presence of TDZ in the culture medium, such as stress conditions (Saher et al., 2004); the high humidity characteristic of in vitro cultures; nutritional conditions, such as mineral and carbohydrate levels; and low luminosity (Majada et al., 2000). Nevertheless, it must be noted that high levels of phytoregulators are the most frequent cause of plant physiological disorders, such as hyperhydricity (Majada et al., 2000).

Hyperhydricity induced by cytokines may be more difficult to reverse, particularly in cases where the phytoregulator is required for proliferation (Palma et al., 2011). The presence of TDZ caused low shoot regeneration and high hyperhydricity in Aloe polyphylla, and this effect seemed to be species-specific (Ivanova and Staden, 2011). In Gypsophila paniculata, the highest percentage of hyperhydricity (49.5\%) occurred in the absence of NAA (Quoirin et al., 2008).

The use of certain cytokines, especially TDZ, may cause hyperhydricity (Barrueto, 2000). Among the cytokines whose effects on multiplication were tested, TDZ induced the highest rates of hyperhydricity in Pyrus pyrifolia plants cultivated in vitro (Kadota and Niimi, 2003). Bosela (2009) observed that this phenomenon appeared in several Populus hybrids when the nutritive medium was supplemented with antibiotics, which induced a significantly higher rate of hyperhydricity when combined with TDZ.

\section{CONCLUSION}

The highest number of shoots per explant and the average number of adventitious buds is observed with the combined use of $0.5 \mu \mathrm{M}$ NAA and $32 \mu \mathrm{M}$ TDZ.

The lowest percentage of callus formation occur in the absence of phytoregulators. However, the presence of calli do not affect plant development in vitro.

No hyperhydricity is observed at TDZ concentrations associated with the highest averages of shoot and bud formation.

Revista Árvore. 2017;41(5):e410509 


\section{ACKNOWLEDGEMENTS}

We thank CNPq for the fellowships awarded.

\section{REFERENCES}

Akram M, Aftab F. High frequency multiple shoot formation from nodal explants of teak (Tectona grandis L.) induced by thidiazuron. Propagation of Ornamental Plants. 2008;8(2):72-5.

Backes A, Irgang B. Árvores do Sul: guia de identificação e interesse ecológico. Porto Alegre: Pallotti; 2002.

Baque MA, Hahn EJ, Paek KY. Induction mechanism of adventitious root from leaf explants of Morinda citrifolia as affected by auxin and light quality. In vitro Cellular and Developmental Biology - Plant. 2010;46:71-80.

Barrueto LPC. Citocininas. In: Barrueto LPC editor. Introdução aos hormônios vegetais. Brasília: Embrapa/Cenargen; 2000. p.55-81.

Bosela MJ. Effects of lactam antibiotics, auxins, and cytokinins on shoot regeneration from callus cultures of two hybrid aspens, Populus tremuloides x P. tremula and P. x canescens x P. gradidentata. Plant Cell, Tissue and Organ Culture.2009;98(3):249-61.

Carvalho PE. Espécies arbóreas brasileiras. Brasília, DF: Embrapa Informação Tecnológicas; Colombo: Embrapa Florestas; 2008.

Cortizo M, Diego N, Moncaleán P, Ordás RJ. Micropropagation of adult Stone Pine (Pinus pinea L.). Trees - Structure and Function. 2009;23(4):835-42.

Costa GM, Nepomuceno CF, Santana JRF. Propagação in vitro de Erythrina velutina. Ciência Rural. 2010;40(5):1090-6.

Faisal M, Ahmad N, Anis M. Shoot multiplication in Rauvolfia tetraphylla L. using thidiazuron. Plant Cell, Tissue and Organ Culture. 2005;30(2):187-90.

Fermino Júnior PCP, Raposo A, Nagao EO, Scherwinski-Pereira JE. Efeito de diferentes citocininas e sistema de cultura dupla-fase na micropropagação de Teca (Tectona grandis L.) estabelecida na Amazônia Sul- Ocidental. Evidência. 2014;14:7-20.

Ferreira DF. SISVAR: a Guide for its Bootstrap procedures in multiple comparisons. Ciência e Agrotecnologia. 2014;38(2):109-12.

Golle DP. Estabelecimento, multiplicação, calogênese, organogênese in vitro e análise da diversidade genética em acessos de Eugenia involucrata DC [tese] Santa Maria: Universidade Federal de Santa Maria; 2010.

Golle DP, Reiniger LRS. Fitorreguladores e posição de explantes foliares na indução à calogênese em cerejeira-do-mato. Ciência Rural. 2013;43(10):1759-62.

Hinojosa GF. Auxinas. In: Barrueto Cid LP editor. Introdução aos hormônios vegetais. Brasília, DF: Embrapa/Cenargen; 2000. p.15-53.

Ivanova M, Staden JV. Influence of gelling agent and cytokinins on the control of hyperhydricity in Aloe polyphylla. Plant Cell, Tissue and Organ Culture. 2011;104:13-21.

Kadota M, Niimi Y. Effects of cytokinin types and their concentrations on shoot proliferation and hyperhydricity in in vitro pear cultivar shoots. Plant Cell, Tissue and Organ Culture. 2003;72(3):261-5.

Kozgar M, Shahzad A. An improved protocol for micropropagation of teak tree (Tectona grandis L.). Rendiconti Lincei. 2012;23(2):195-202.

Li Z, Mize K, Campbell F. Regeneration of daylily (Hemerocallis) from young leaf segments. Plant Cell, Tissue and Organ Culture. 2010;102(2):199-204.

Lorenzi H. Árvores brasileiras: manual de identificação e cultivo de plantas arbóreas nativas do Brasil. $5^{\mathrm{a}}$. ed. Nova Odessa: Instituto Plantarum; 2008. 384p.

Ma XY, Yi GJ, Huang XL, Zeng JW. Leaf callus induction and suspension culture establishment in lychee (Litchi chinensis Sonn.) cv. Huaizhi. Acta Physiologiae Plantarum. 2009;31(2):401-5.

Majada JP, Tadeo F, Fal MA, Sánchez-Tamés R. Impact of culture vessel ventilation on the

Revista Árvore. 2017;41(5):e410509 
anatomy and morphology of micropropagated carnation. Plant Cell, Tissue and Organ Culture. 2000;63:207-14.

Moreira MA, Carvalho JGD, Pasqual M, Fráguas $\mathrm{CB}$, Silva ABD. Efeito de substratos na aclimatização de mudas micropropagadas de abacaxizeiro cv. pérola. Ciência e Agrotecnologia. 2006;30(5):875-9.

Murashige T, Skoog F. A revised medium for rapid growth and bio assays with tobacco tissue cultures. Physiologia Plantarum. 1962;15:473-97.

Oliveira LS, Dias PC, Brondani GE.

Micropropagação de espécies florestais brasileiras. Pesquisa Florestal Brasileira. 2013;33(76):439-53.

Palma D, Schuelter AR, Stefanello S, Fortes AMT. Aspectos morfofisiológicos e controle da hiperidricidade na cultura de tecidos vegetais. Revista Brasileira de Agrociência. 2011;17(2-4):174-84.

Pereira DMS, Oliveira LM, Nepomuceno CF, Santana JRF, Silva MLC, Koblitz MGB. Induction and morphological and biochemical characterization of Hyptis leucocephala (Lamiaceae) calluses. Sitientibus Série Ciências Biológicas. 2012;12(1):151-6.

Pinto DLP, Barros BA, Viccini LF, Campos JMS, Silva ML, Otoni WC. Ploidy stability of somatic embryogenesis-derived Passiflora cincinnata Mast. plants as assessed by flow cytometry. Plant Cell, Tissue and Organ Culture. 2010;103:71-9.

Quoirin MGG, Biasi LA, Rios JF, Cuquel FL. Micropropagação de Gypsophila pela cultura de segmentos nodais. Scientia Agraria. 2008;9:79-83.

Resende MDV. Melhoramento de espécies perenes. In: Nass LL, Valois ACC, Melo IS, Valadares-Inglis MC editores. Recursos genéticos e melhoramento de plantas. Rondonópolis: Fundação Mato Grosso; 2001. p.356-421.

Rubin S, Lima CSM, Bandeira JM, Ribeiro MV, Benitez LC. Reguladores de crescimento na multiplicação in vitro de Thymus vulgaris L.
Revista Brasileira de Biociências. 2007;5(supl.2):480-2.

Saher S, Piqueras A, Hellin E, Olmos E. Hyperhydricity in micropropagated carnation shoots: the role of oxidative stress. Physiologia Plantarum. 2004;120:152-61.

Siddique I, Anis M. In vitro shoot multiplication and plantlet regeneration from nodal explants of Cassia angustifolia (Vahl.): a medicinal plant. Acta Physiologiae Plantarum, 2007;29(3)223-38.

Siddique I, Anis M. Direct plant regeneration from nodal explants of Balanites aegyptiaca L. (Del.): a valuable medicinal tree. New Forests. 2009;37(1):53-62.

Silva ML, Pinto DLP, Guerra MP, Floh EIS, Bruckner $\mathrm{CH}$, Otoni WC. A novel regeneration system for a wild passion fruit species (Passiflora cincinnata Mast.) based on somatic embryogenesis from mature zygotic embryos. Plant Cell, Tissue and Organ Culture. 2009;99:47-54.

Silva TS, Nepomuceno CF, Borges BPS, Alvim BFM, Santana JRF. Multiplicação in vitro de Caesalpinia pyramidalis (Leguminosae). Sitientibus série Ciências Biológicas. 2013;13:1-6.

Sousa NL. Desenvolvimento de sistemas para transformação genética de mamona (Ricinus communis L.) - as bases para o silenciamento da ricina [dissertação]. Brasília, DF: Universidade de Brasília; 2013.

Sujatha K, Hazra S. Micropropagation of mature Pongamia pinnata Pierre. In Vitro Cellular and Developmental Biology - Plant. 2007;43(6):608-13.

Tzfira T, Zuker A, Altman A. Forest-tree biotechnology: genetic transformation and its applications to future forests. Trends in Biotechnology. 1998;16(10):439-46.

Xavier A, Otoni WC, Penchel RM. Micropropagação e enxertia in vitro de espécies florestais. In: Borém A. editor. Biotecnologia florestal. Viçosa, MG: UFV; 2007. p.55-74. 